\title{
MODELLING OF LOW ENERGY X-RAY SCATTERING IN RADIATION DETECTORS WITH PROTECTIVE COATINGS
}

\author{
I. Cibulskaitė, D. Adlienè, and J. Laurikaitienè \\ Kaunas University of Technology, Studentu 50, LT-51368 Kaunas \\ E-mail: agnici@gmail.com
}

Received 21 February 2008; revised 25 July 2008; accepted 18 September 2008

\begin{abstract}
The results of Monte Carlo modelling of the low energy X-ray photon interaction processes in Si detector coated by different materials of different thickness are presented in this paper. Detector constructions containing free standing polymer-like carbon coatings and diamond-like carbon (DLC) coatings deposited onto detector surface were investigated. Total and scatter doses in coated samples were calculated and the influence of the coating material, composition, and thickness on the X-ray photon scattering processes in Si detector was evaluated. Evaluation of the detector construction with protective coating corresponding to the lowest fraction of scattered photons as compared to the calculated total dose is discussed in the paper. It is shown that nano-thick DLC coatings directly deposited onto detector surface are promising materials in the construction of radiation detectors due to their suitable mechanical properties, resistance against chemicals and against radiation damage of DLC films.
\end{abstract}

Keywords: scattered radiation, detectors, Monte Carlo method, DLC films

PACS: 02.70.Uu, 29.40.Wk, 32.80.Cy, 81.05.Uw, 81.40.Wx

\section{Introduction}

The effectiveness of radiation detection depends on the method and the type of detector chosen for the registration $[1,2]$. Solid state detectors (luminescent detectors, semiconductor devices) are widely used for the registration of radiation doses to patients during medical procedures $[3,4]$. However, application of solid state detectors is limited by detector's size, geometry, construction, properties of detector material, and equivalence to biological tissue. One of the most important problems in detecting the X-ray photons with $\mathrm{Si}$ based detectors is radiation induced scattering effects in detector material. Scattering effects reduce the fraction of directly absorbed X-ray photons in detector material and are responsible for the increased patient's dose necessary for keeping the required quality of the examination. Some solutions have been found [5-7] during last years, which allow to evaluate and reduce scattering effects of high energy (6-20 MeV) X-ray photons in detector material, when Si detectors are used for the estimation of the radiation dose delivered to the patients during radiotherapy procedure. However, the evaluation of the scattering processes (coherent and Compton) of low energy (20-35 keV) X-ray photons in detector materials and the assessment of their influence on the registered doses to patients remains opened and limits the possible application of Si based detectors in mammography screening examinations. Some attempt to compare the experimental and Monte Carlo modelling results concerning low energy photon scattering effects in Si detectors and to evaluate the influence of scattering processes on the absorbed total dose to patient has been made in our previous work [8]. Previous results on Monte Carlo simulation of low energy X-ray photon scattering effects in different materials are presented in $[9,10]$. However, the existing information is not sufficient for understanding the discrepancies that occur between experimental and modelling data.

Scattering effects in diamond are significantly lower as compared to silicon. Due to the excellent mechanical, optical, and electrical properties, diamond detector alone could be theoretically used, without any protective coating $[11,12]$. Still, diamond is very expensive material, so other materials have to be considered for the application in the construction of solid state detectors. Materials used as radiation sensing elements of detectors are usually coated by (at least from the radiation entrance side) or encapsulated into a protective layer, which represents a free standing foil, or a thin film, deposited on the surface of the active layer using physical and chemical methods. Carbon based polymeric ma- 
terials are widely used as protective coatings for radiation detectors. Usually they are relatively thick and free standing, thus having no physical/ chemical contact with the detector surface. Correspondence of the physical properties of the DLC coatings to those of diamond [13-15] and the possibility to deposit DLC coatings of nanoscale thickness directly on the detector surface makes them very promising for the application as protective coatings in the construction of radiation detectors.

There are only few investigations on the influence of the coating to the scattering processes in the active volume of the detector: the results of calculations using deterministic model for the photon scattering process description in coated material are presented in [16], as well as the results of Monte Carlo based modelling of scattered radiation in $\mathrm{Al}_{2} \mathrm{O}_{3}$ detector, encapsulated into different free standing polymer-like carbon containing foils - in [17].

The aim of this work was to perform Monte Carlo modelling of a low energy X-ray photon transport in Si detector coated by different free standing polymerlike carbon coatings or DLC coatings deposited directly onto detector surface, to assess the influence of different coating materials on the scattering processes in the active volume of the detector, to evaluate relative scattered doses, and to discuss detector construction with the protective coating, which ensures lowest possible fraction of scattered photons as compared to the calculated total dose. Monte Carlo modelling was performed in accordance with the real X-ray exposure conditions of patients in diagnostic mammography screening examination.

\section{Instruments and methods}

Three main physical processes dominate when low energy photons (20-35 keV) interact with materials, which are characterized by $Z_{\text {eff }}$ similar to this of the soft tissue, and are preferred in the construction of radiation detectors used for the dose measurements: electron photoabsorption, coherent (Rayleigh) scattering, and incoherent (Compton) scattering [18]. We will concentrate on the modelling of X-ray photon scattering effects in coated Si specimens, since scattered photons are responsible for the reduced intensity of the registered signal and for the increased noise level in detector material [19]. On the other hand, scattering processes influence entrance surface dose (ESD), which is used for the calculation of the average glandular dose (AGD) in the patient's breast tissue [20,21]:

$$
\mathrm{AGD}=\frac{\mathrm{ESD}}{b} g c s,
$$

where $b$ is backscatter factor, $g$ is the glandularity conversion factor, $c$ is conversion factor for $50 \%$ glanularity, $s$ is the spectral conversion factor.

\subsection{Experimental set-up}

Investigation of the scattering processes in coated $\mathrm{Si}$ was performed using experimental model that was developed in accordance with the real exposure conditions present during mammography screening examinations of patients (Fig. 1).

It was assumed that X-ray photons are generated in molybdenum target of mammography unit ALPHA RT (Instrumentarium Imagining, Finland) at the X-ray tube potentials ranging from 25 to $32 \mathrm{kV}$, when the tilting angle of the Mo anode is $16^{\circ}$. Generated

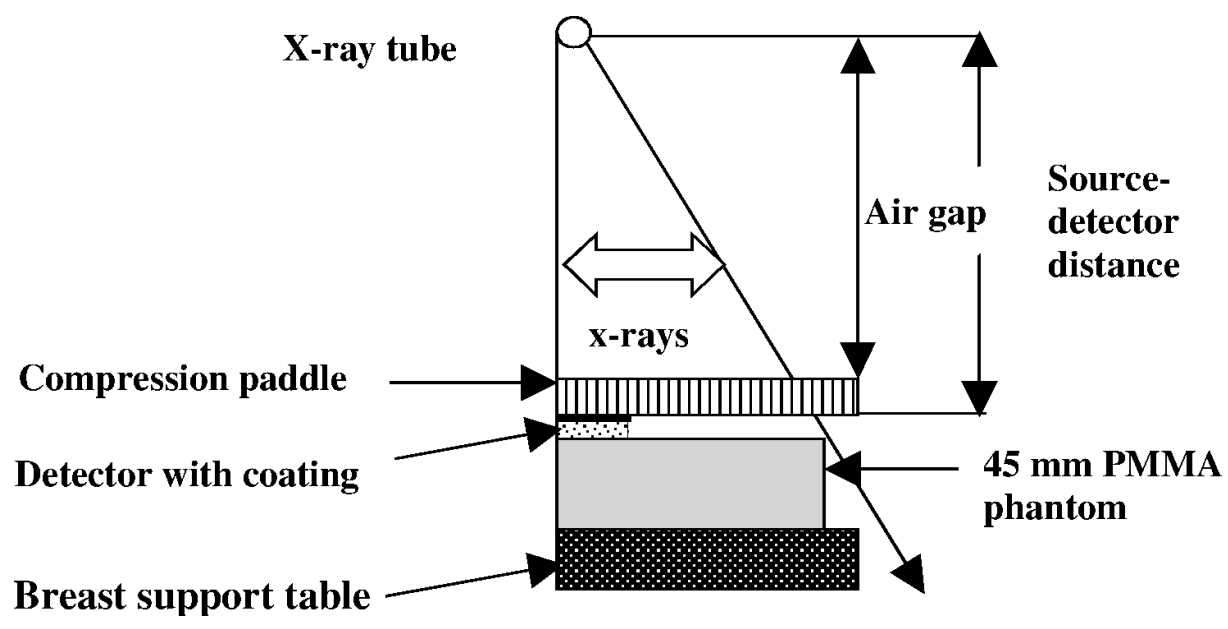

Fig. 1. Simplified geometry of the experimental set-up (not in scale). 


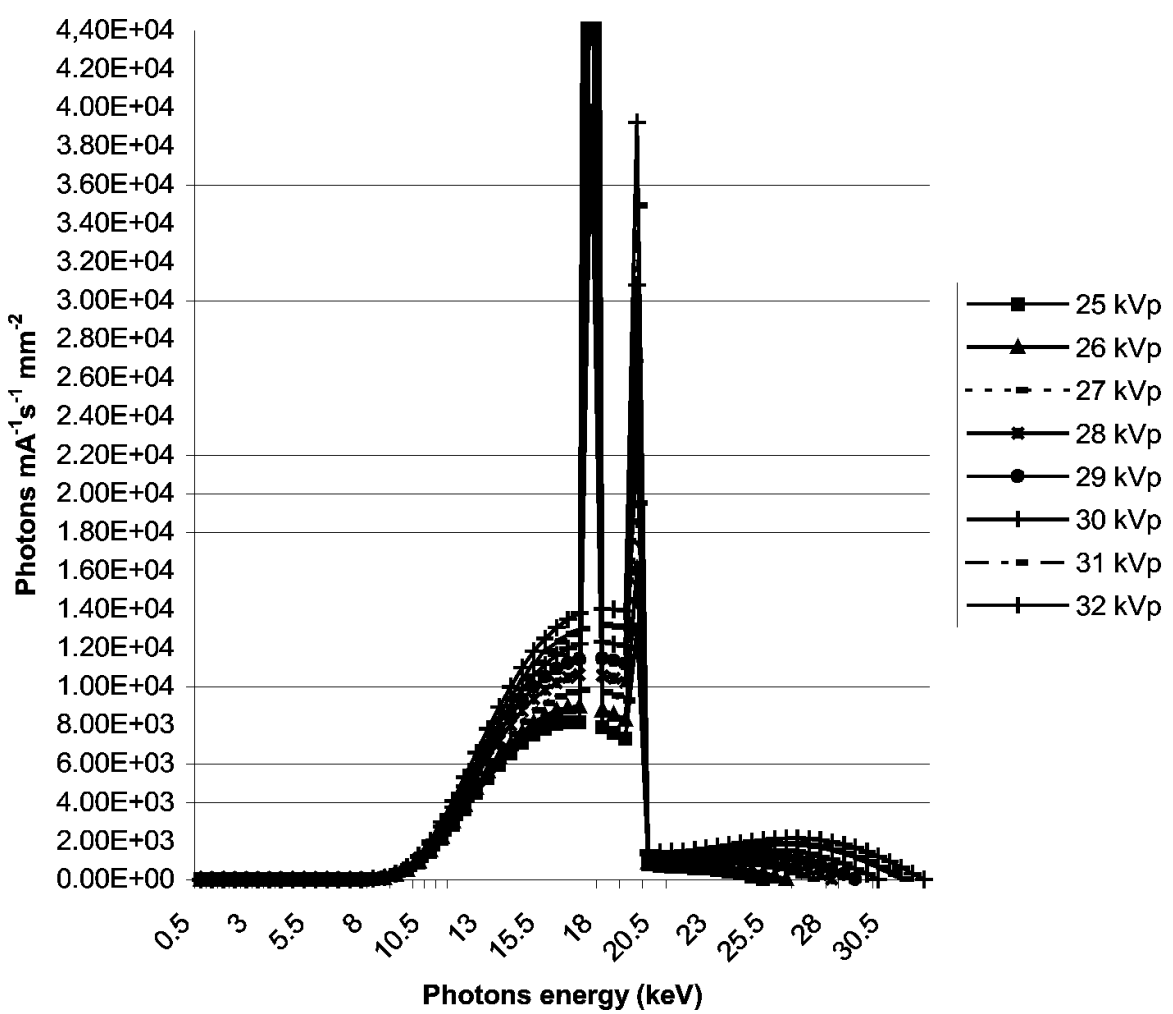

Fig. 2. Processed molybdenum X-ray spectrum for the different X-ray tube potentials.

$\mathrm{X}$-ray beams are attenuated by $1 \mathrm{~mm}$ Be window of the X-ray tube, $0.03 \mathrm{~mm}$ Mo filter, and $3 \mathrm{~mm}$ thick polymethymethacrylate compression paddle of mammography unit. $45 \mathrm{~mm}$ thick polymethylmethacrylate (PMMA) phantom representing "standard" female breast is used instead of patient. Additional filtration of the photons with the energies below about $10 \mathrm{keV}$ and above $20 \mathrm{keV}$ is included, due to the fact that Mo is characterized by $\mathrm{K}$ lines at the energies of $17.38\left(\mathrm{~K}_{\alpha 2}\right)$, $17.49\left(\mathrm{~K}_{\alpha 1}\right), 19.61\left(\mathrm{~K}_{\beta 1}\right)$, and $19.96\left(\mathrm{~K}_{\beta 2}\right) \mathrm{keV}$ [22]. Polyenergetic X-ray photon spectra for different tube potentials in the case of the constant source-detector distance (Fig. 2) were processed using the routines of IPEM Spectrum Processor [23], which were modified according to the experimental set-up.

Low energy photons generated in mammography unit enter the surface of coated specimens having estimated energetic spectral distribution and interact with both coating material and target material. We distinguished two different cases for the "coating-detector" arrangements:

- target (detector) is covered with or encapsulated into a free standing polymer-like carbon coating as it is shown in Fig. 3(a). There are no chemical bonds between coating and bulk material, only negligible thin air layer in between;

- amorphous DLC coating is synthesized on Si wafer using direct ion beam deposition method [24], as it is indicated in Fig. 3(b). Coating is deposited onto detector surface having physical contact and common chemical bonding structure.

$p$-type $\mathrm{Si}\langle 111\rangle$ as a bulk material was used in our investigations. Some characteristics of coating materials are presented in Table 1.

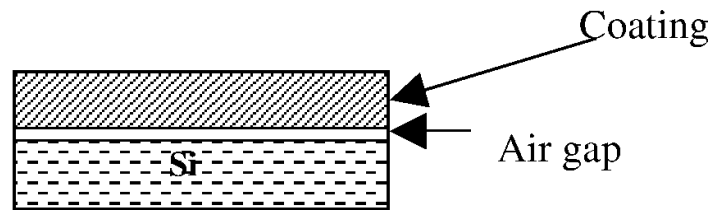

(a)

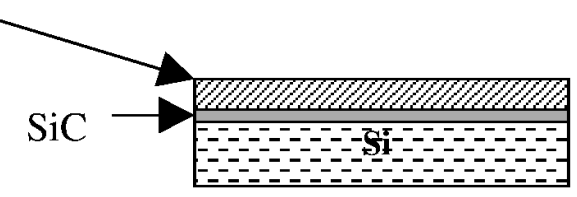

(b)

Fig. 3. Cross-sections of the investigated coated structures: (a) Si crystal covered by free standing polymer-like carbon coating, (b) Si crystal with deposited DLC film on its surface. 
Table 1. Some characteristics of coating materials (taken from diverse literature sources).

\begin{tabular}{ccrrr}
\hline Coating type & Coating material & Composition & $Z_{\text {eff }}$ & Density, $/ \mathrm{cm}^{3}$ \\
\hline \multirow{2}{*}{$\begin{array}{c}\text { Free standing } \\
\text { polymer-like } \\
\text { carbon }\end{array}$} & Polyethylene & $14 \% \mathrm{H}, 85 \% \mathrm{C}$ & 5.68 & 0.93 \\
\cline { 2 - 6 } & Mylar, polyethyleneterephthalate & $4 \% \mathrm{H}, 62 \% \mathrm{C}, 33 \% \mathrm{O}$ & 6.71 & 1.38 \\
\hline $\begin{array}{c}\text { Directly deposited } \\
\text { amorphous DLC film }\end{array}$ & Rubber & $11 \% \mathrm{H}, 88 \% \mathrm{C}$ & 5.75 & 0.92 \\
\cline { 2 - 6 } & $\mathrm{SiO}_{x}$-containing DLC film synthesized from HMDSO & $54 \% \mathrm{C}, 27 \% \mathrm{O}, 19 \% \mathrm{Si}$ & 9.15 & 2.20 \\
\hline
\end{tabular}

\subsection{Theoretical model for the description of photon scattering processes}

It is assumed that coherent and incoherent scattering events may occur, if low energy photon interacts with the atoms of target material.

Coherent or Rayleigh scattering is characterized by scattering of photon without excitation of atoms. To describe this scattering process we have used following atomic differential cross-section per unit solid angle $\Omega=(\theta, \phi)$ :

$$
\frac{\mathrm{d} \sigma_{\mathrm{R}}}{\mathrm{d} \Omega}=\frac{r_{0}^{2}}{2}\left(1+\cos ^{2} \theta\right)\left[F_{T}(x)\right]^{2},
$$

where $F_{T}(x)$ is the atomic form factor, given as

$$
\left[F_{T}(x)\right]^{2}=\sum p_{i}\left[F_{T}\left(x, Z_{i}\right)\right]^{2},
$$

with the stoichiometric index of the $i$ th element $p_{i}$, atomic number $Z_{i}$, and momentum transfer $x$ when a photon with the energy $k$ is scattered by polar scattering angle $\theta$ :

$$
x=k \sqrt{\frac{1-\cos \theta}{2}} .
$$

The quantity $r_{0}$ is the classical electron radius.

The differential cross-section for Rayleigh scattering from an amorphous material [25] is given by

$$
\frac{\mathrm{d} \sigma_{\mathrm{R}}}{\mathrm{d} \cos \theta}=\pi r_{0}^{2}\left(1+\cos ^{2} \theta\right)\left|F_{\mathrm{R}}(x)\right|^{2},
$$

where $F_{\mathrm{R}}(x)$ is the form factor and $x=\sin (\theta / 2) \lambda$ is the momentum transfer. The form factor for an amorphous material is given by [26]

$$
\left|F_{\mathrm{R}}(x)\right|^{2}=s(x) \sum_{i} w_{i}\left|F_{\mathrm{R} i}(x)\right|^{2}
$$

where $w_{i}$ and $F_{\mathrm{R} i}(x)$ are, respectively, the atom fraction and atomic form factor of the $i$ th element in the material and $s(x)$ is the structure function that accounts for diffraction effects. For an amorphous material, integrating Eq. (5) gives total Rayleigh scattering cross-section, which is sampled when a Rayleigh event occurs.
Modified model, which includes binding effects of the electron and takes into account Doppler broadening, was used for the description of Compton scattering process. Applying this enhanced model, the incoherent scattering cross-section, differential in the photon scattering angle, is given by

$$
\frac{\mathrm{d} \sigma_{\mathrm{Compt}}}{\mathrm{d} \Omega}=\frac{r_{0}^{2}}{2}\left(\frac{k_{c}}{k}\right)^{2} X_{\mathrm{KN}} S(k, \cos \theta),
$$

where $k$ is the energy of the interacting photon, $k_{c}$ is the energy of a photon scattered at angle $\theta$ by free electron at rest, $X_{\mathrm{KN}}$ is Klein-Nishina function [27], and $S(k, \cos \theta)$ is the so-called $S$-matrix [28], which identifies incoherent scattering function:

$$
S(k, \cos \theta)=\sum Z_{i} \Theta\left(k-U_{i}\right) S_{i},
$$

with $Z_{i}$ as an occupational number of the shell $i, U_{i}$ as a binding energy, and

$$
S_{i}=\int_{-\infty}^{p_{i}} \mathrm{~d} p_{z} J_{i}\left(p_{z}\right) F\left(k, \cos \theta, p_{z}\right)
$$

where $J_{i}\left(p_{z}\right)$ is one-electron shell Compton profile, which represents wave function of bound electrons and could be approximated as follows [29]:

$$
J_{i}\left(p_{z}\right)=J_{i, 0}\left(1+2 J_{i, 0}\left|p_{z}\right|\right) \exp \left[\frac{1}{2}-\frac{\left(1+2 J_{i, 0}\left|p_{z}\right|\right)^{2}}{2}\right],
$$

where $J_{i, 0} \equiv J_{i}(0)$ is the profile for $p_{z}=0$, obtained from Hartree-Fock shells, $p_{z}$ is projection of the initial electron momentum on the direction $\boldsymbol{x}$, where $\boldsymbol{x}$ is momentum transfer vector.

A more detailed description of the theoretical model was given in our previous work [8]. This model was developed on the basis of particle transport theory [30] and was used both for dose calculations in the active volume of crystalline detector and for modelling of $\mathrm{X}$-ray interaction processes in coating materials. 


\subsection{Monte Carlo modelling platform}

Interactions of low energy polyenergetic X-ray photons with matter were simulated using EGSnrc Code system [31] according to the empirical model described above. Individual photon histories were simulated and the history of each photon was followed until either all of its energy was transferred to electrons or it was absorbed locally due to the scattering events. It was assumed that $10^{8}$ photons (in the case of free standing coating) and $10^{9}$ photons (in the case of deposited DLC film), having a stepwise (in $1 \mathrm{keV}$ increments) increasing energy in the range from 1 to $35 \mathrm{keV}$, in parallel beam interacted with a coated sample. Sample is centrally placed on the top of PMMA phantom of $45 \mathrm{~mm}$ thickness, representing compressed female breast as shown in Fig. 1. Assumption of parallel X-ray beam was made taking into account detector size, which was much smaller than the exposed area $\left(12 \times 12 \mathrm{~cm}^{2}\right)$. Monte Carlo simulations were performed within cylindrical geometry, virtually dividing the X-ray exposed space between compression paddle and breast support table into zones, corresponding to the different densities and compositions of presented materials as it was described in our previous work [8]. It was also assumed that photon beam was parallel to $z$ axis in the central zone of interaction.

Total and scattering doses in coating samples were calculated using modified user code DOSnrc (EGSnrc) [32] in each region of interest The influence of different type, material composition, and thickness of coatings on the scattering processes in Si target was investigated. Processed X-ray spectra (Fig. 2) were used as an input data for the calculations.

\section{Results and discussions}

Despite the fact that Compton scattering was discovered more than 100 years ago, there are some important areas, which still need to be investigated. One of such areas is low energy Compton scattering, which is presented when low energy (20-35 keV) X-ray photons interact with human tissue [28]. It is impossible to measure directly absorbed dose in tissue. Tissue equivalent detectors could be applied instead of human tissue for the registration of the surface dose, which is the main parameter for the further calculations of absorbed dose. It is well known [33] that dose measurements using solid state detector are affected by scattering radiation which decreases signal to noise ratio [18]. However, the assessment of the scatter dose is a complicated task [34]. We have used Monte Carlo modelling for the estimation of the total dose and scatter dose in crystalline detector material with and without coating. Total dose represents the energy transferred to the target (active volume of the detector). Scatter dose is defined as a dose that can be traced back to the photons that have been scattered in Compton and Rayleigh effects and to the photons that were created through relaxation processes after Compton and photoelectric events. It is assumed that the doses are calculated after the interaction of X-ray beam with coating material in the case of coated specimens.

The results of dose calculations in different commonly used radiation detector materials after their irra-

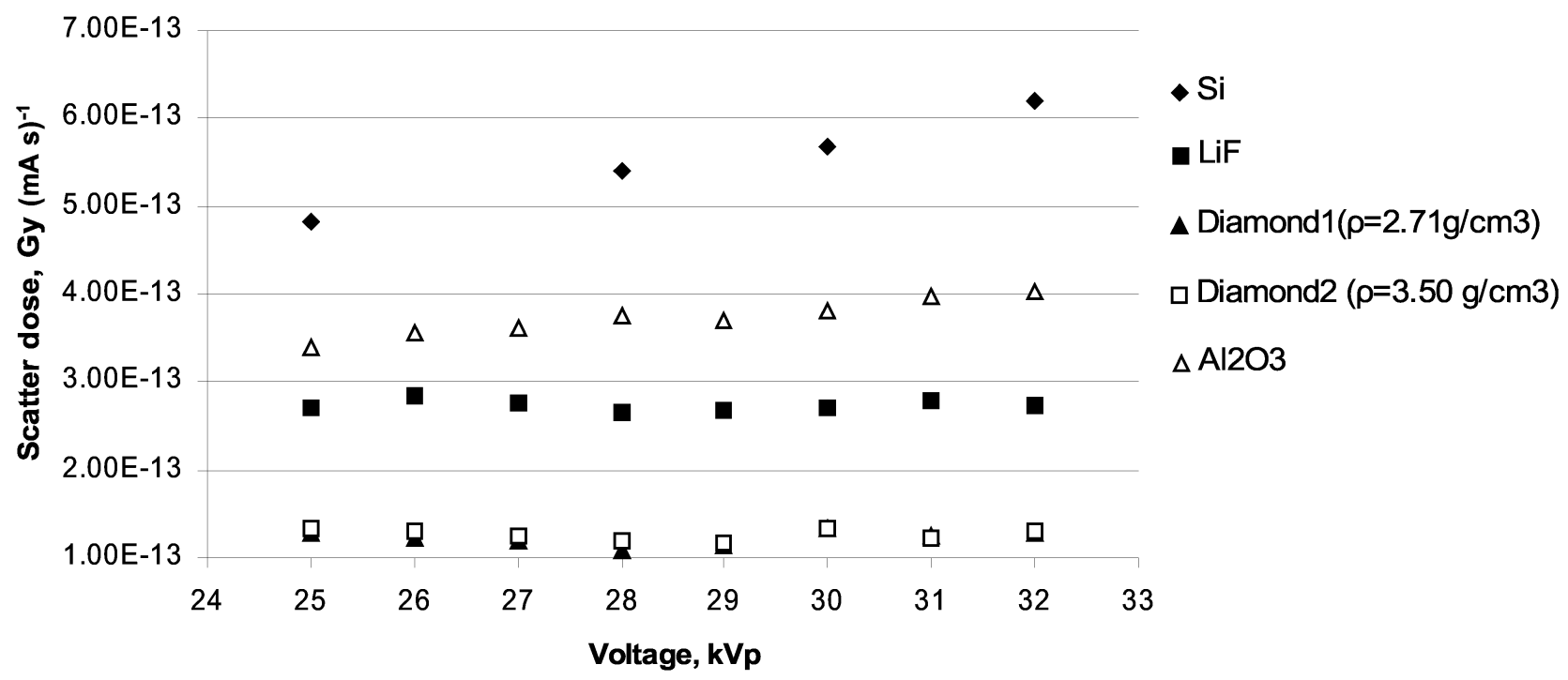

Fig. 4. Scatter dose in different detector materials of the same thickness. 


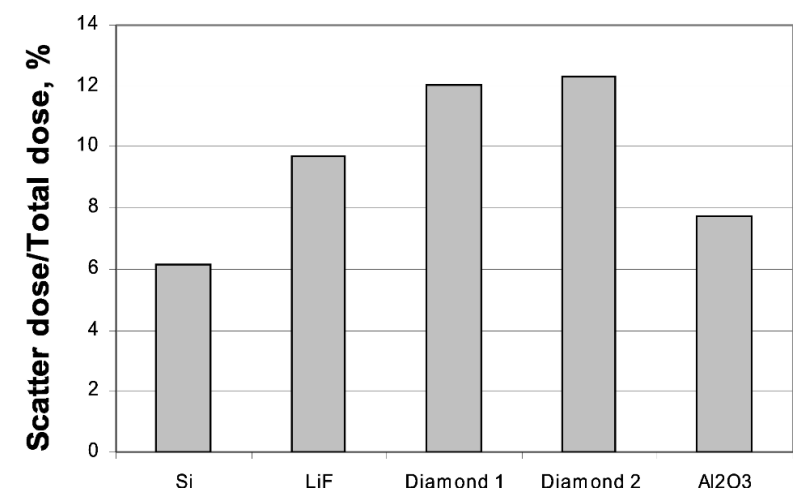

Fig. 5. Scatter to total dose ratio in different detector materials of the same thickness (at $30 \mathrm{kV}$ peak voltage, $\mathrm{kVp}$ ).

diation with low energy X-rays are presented in Fig. 4. The highest scatter dose has been found in $\mathrm{Si}$. It could be attributed to the dependence of at least Compton effect on electron density in different materials. However, the numerical evaluation of the influence of scattering effects expressed as scatter to total dose ratio and performed in this work shows that $\mathrm{Si}$, having low dose ratio, is a good candidate for the registration of low energy X-ray photons (Fig. 5).

Thickness of the detector material plays an important role in reducing the scattering dose, since the increase of the detector's active volume corresponds to the increased possibility for the X-ray photons to be absorbed directly by electrons during photoelectric interaction processes. Calculated values of total and scatter doses in $\mathrm{Si}$ samples of different thickness are presented in Figs. 6 and 7 respectively.
It is to point out that the surface of Si crystal is usually covered by different materials according to the construction of radiation detection device. X-ray interaction processes in detector coating are dependent on the structure (polycrystalline, polymer-like, amorphous) of detector material, its thickness, and the type of contact layer between coating and detector surface. Modelling of these processes is very important since they contribute to the attenuation of X-ray beam before it enters a detector crystal.

Calculated scatter doses in the Si samples of different thickness coated by different coatings are presented in Fig. 8. As it could be seen, scatter dose is higher in coated specimens than in uncoated ones due to the energy loss of photons in coating material. Scatter dose increases with the increased density of coating material, however the gap between the dose of uncoated $\mathrm{Si}$ and coated by DLC film one, which represents the highest density $\left(2.2 \mathrm{~g} / \mathrm{cm}^{3}\right)$ of all used coatings, is broader for thinner detectors. No difference in scatter dose of uncoated and coated with nano thin DLC coatings $\mathrm{Si}$ samples was found.

As mentioned above, the thickness of the coating plays an important role in X-ray attenuation processes. To compare the influence of the coating thickness, three possible cases were investigated: (i) $h$ is of the same order as $d$, (ii) $h / d \leq 0.1$, and (iii) $h / d \leq 0.01$, where $h$ indicates thickness of coating and $d$ is thickness of the active volume of the detector. The results of the calculations of dose ratio for the three cases are presented in Fig. 9.

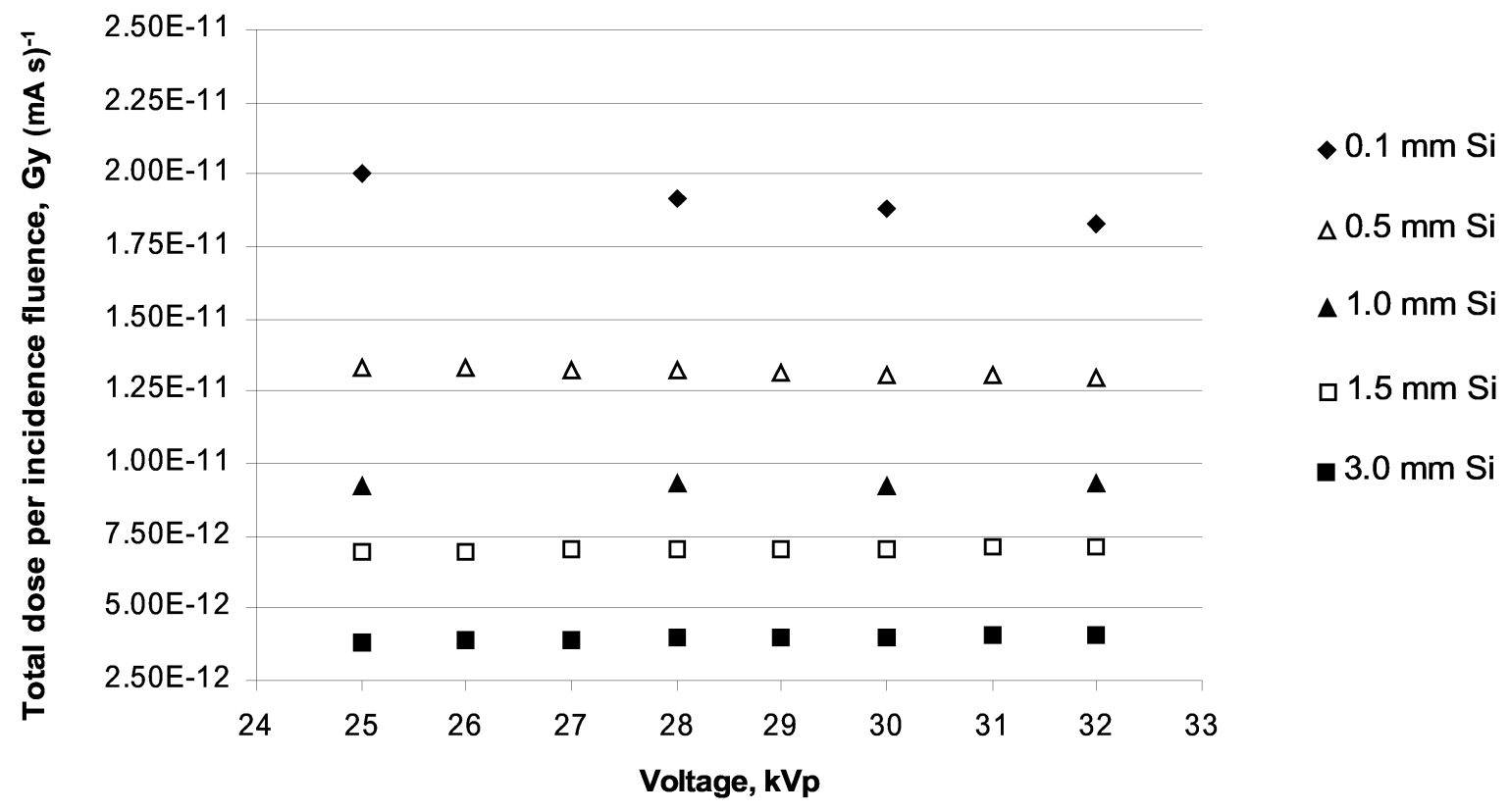

Fig. 6. Total dose transferred to uncoated Si of different thickness. 


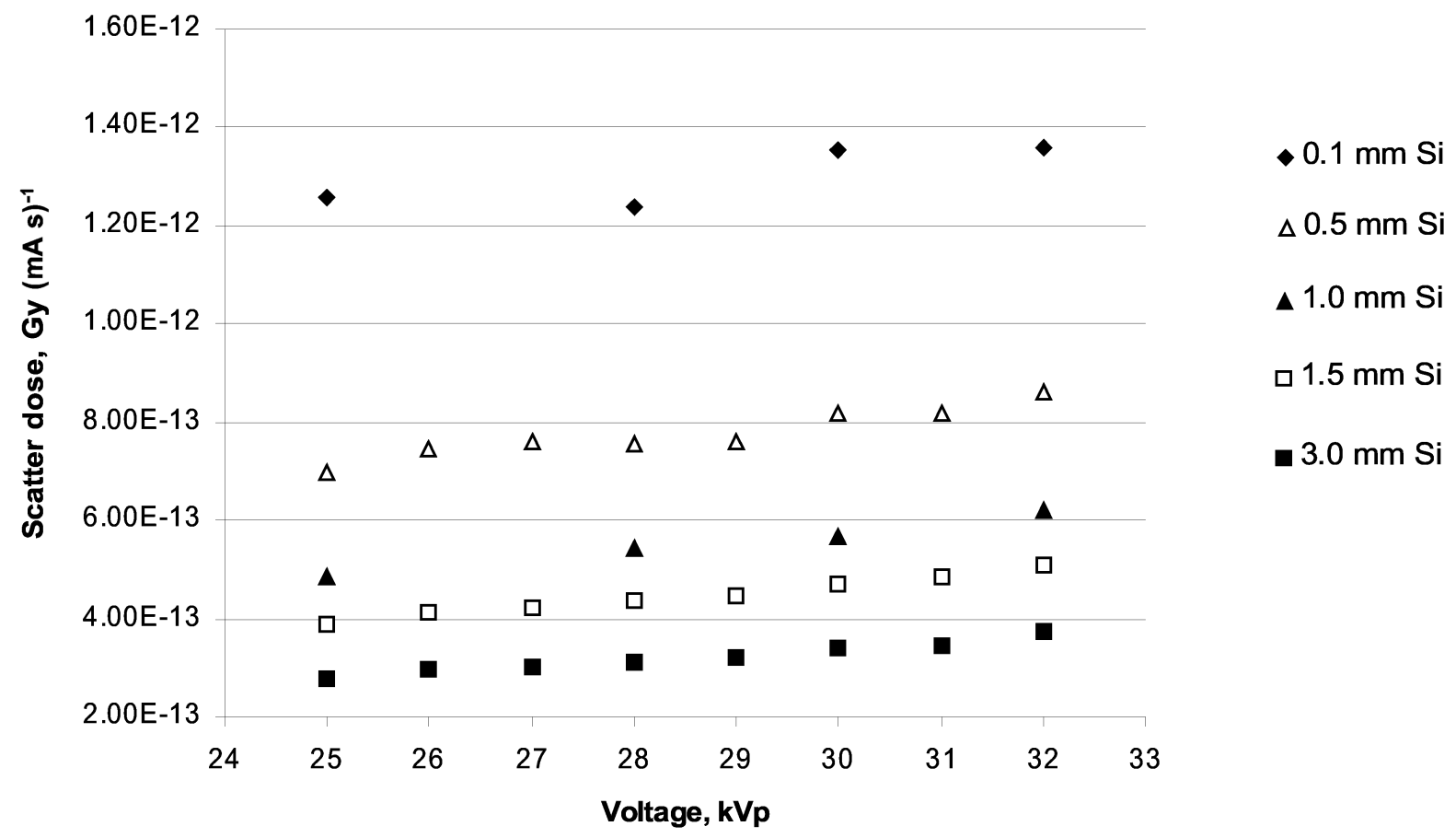

Fig. 7. Scatter doses in uncoated $\mathrm{Si}$ of different thickness $\left(10^{9}\right.$ histories were used for the calculations of $0.1 \mathrm{~mm}$ thick $\left.\mathrm{Si}\right)$.

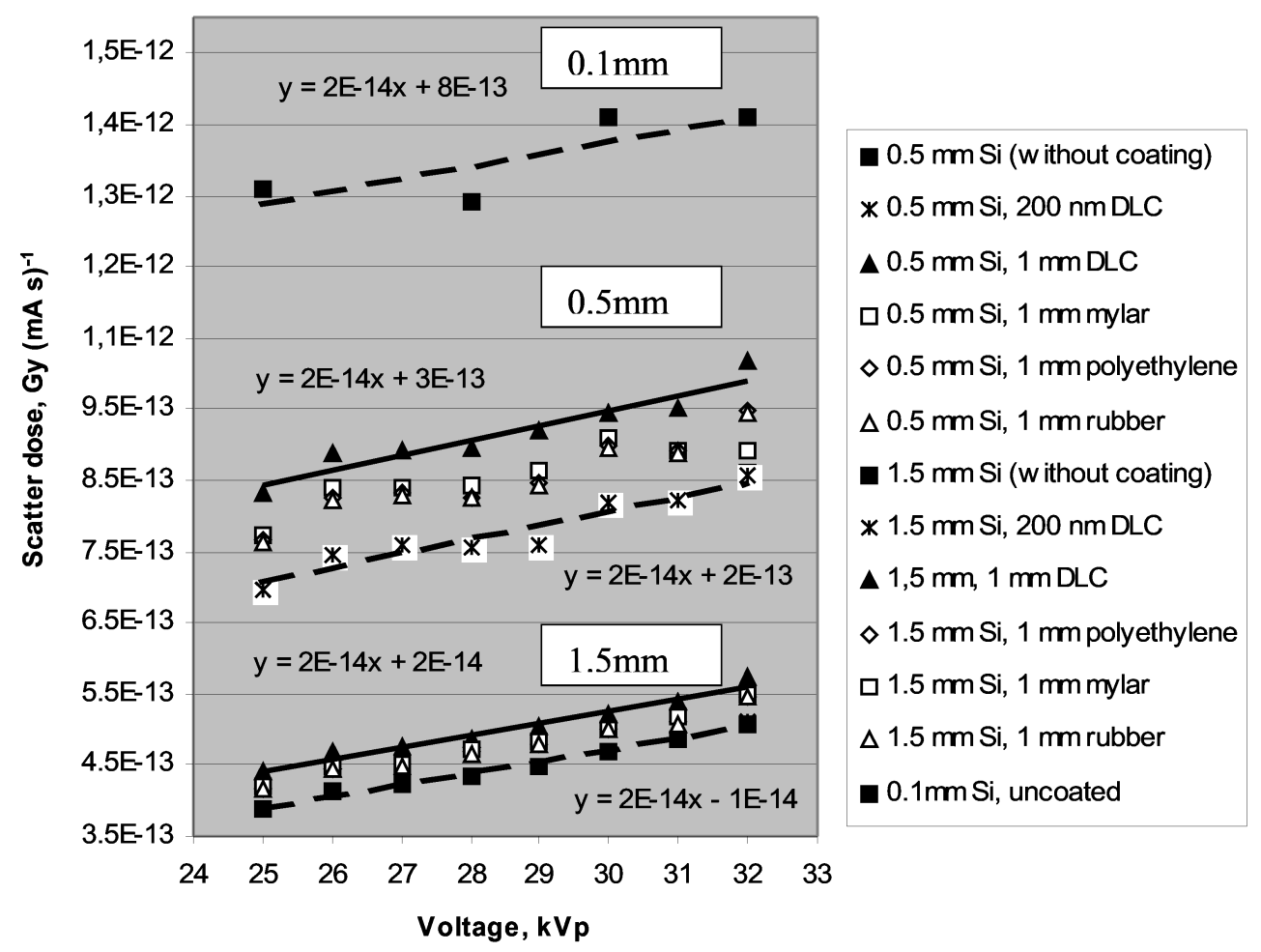

Fig. 8. Scatter dose in Si samples of different thickness coated by the different coatings of the same thickness. (Si coated by nano thick DLC coatings is given for comparison.) 


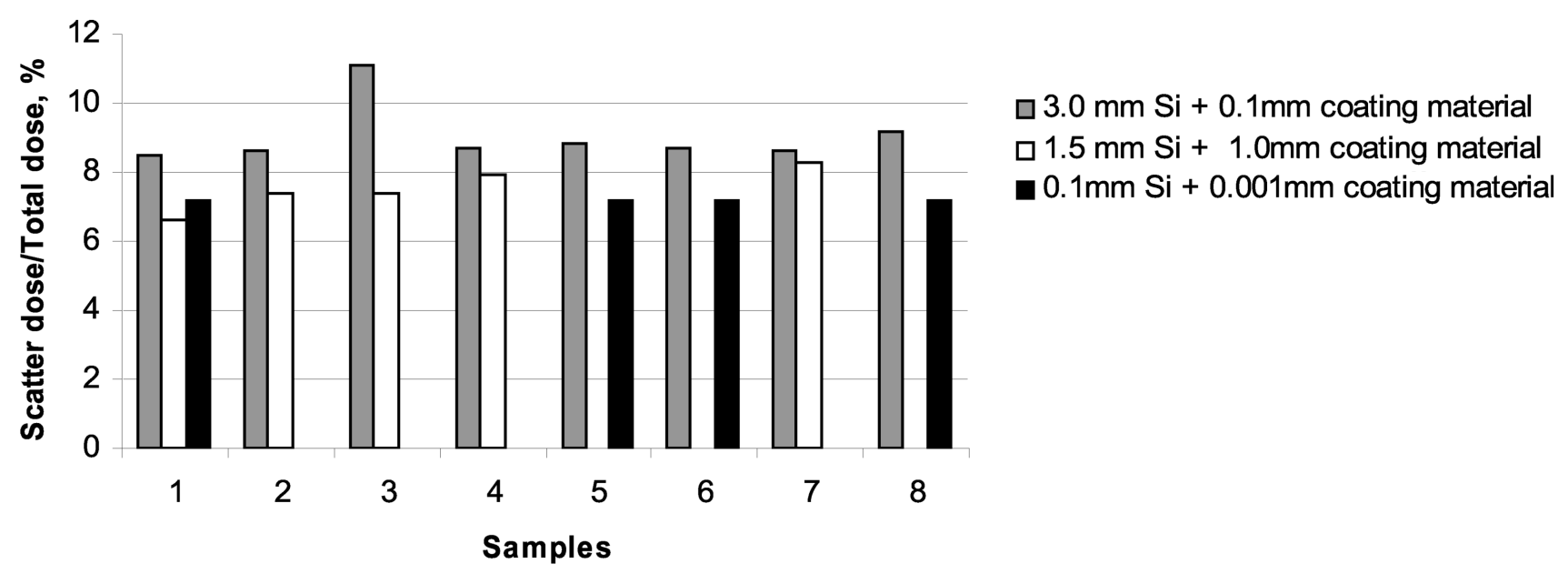

Fig. 9. Variations of the dose ratio in $\mathrm{Si}$ samples coated by different materials: 1 uncoated $\mathrm{Si}, 2 \mathrm{Si}$ coated by rubber, $3 \mathrm{Si}$ coated by polyethylene, $4 \mathrm{Si}$ coated by mylar, $5 \mathrm{Si}$ coated by DLC containing $\mathrm{SiO}_{x}, 6 \mathrm{Si}$ coated by a-C: $\mathrm{H}$ coating, $7 \mathrm{Si}$ coated by carbon fibre, $8 \mathrm{Si}$ coated by $\mathrm{SiO}_{2}$.

Thickness of the coating is one of the limiting parameters in the application of different materials as protective layers against the mechanical, electrical, and chemical influence from the environment, or as passive layers in the principal construction of the detecting device.

\subsection{Influence of protective layer to the scattering dose in $\mathrm{Si}$}

Depending on the goal of the application, relatively thick $(h \approx d)$ or thin $(h / d \leq 0.1)$ free standing layers of mylar, polyethylene, rubber, carbon fibre are used to protect the detector surface [35] against the influence of the surrounding environment. Our calculations show that the dose ratio is higher in the second case $(h / d \leq$ 0.1 ), despite the fact that scatter dose is lower in the thicker detector. Since scatter to total dose ratio corresponds to the registered signal, it is possible to reduce the number of scattering effects in detector material by optimising the coating thickness and to improve the signal to noise ratio. If the thickness of protective layer is extremely small ( $h / d \leq 0.01$, or less) as it is in the case of the direct deposition of DLC film onto detector surface, deposited coating has no influence on X-ray interaction processes within the detector material (Fig. 8). This feature could be used when new detecting devices are under construction. However, attention has to be paid that deposited ultrathin coatings must have almost the same or better protective properties (high hardness, resistance against chemicals, resistance against radiation damage, etc.) as the free standing polymer-like coatings have. According to the results of our recent investigations on the properties of the X-ray photon irradiated DLC films [36,37], radiation damage was neg- ligible in the DLC films after their prolonged irradiation with high $(15 \mathrm{MeV})$ and low $(32 \mathrm{keV}) \mathrm{X}$-ray photons. The hardness of the irradiated DLC structures was even higher after the irradiation. Comparison of some properties of DLC films, which were used in our calculations, with the parameters of other coating materials is provided in Table 2.

Possible deposition of the nano thick film directly onto active detector surface, negligible influence of the presence of thin DLC films on the scattering effects in detector material induced by X-rays, together with the properties outlined in Table 2, makes DLC coatings the promising candidates for protective layers of radiation detectors. It should be acknowledged, though, that the thickness of DLC films is limited due to their adhesive properties [39].

\subsection{Influence of passive layer to the scattering dose in detector device}

$\mathrm{SiO}_{2}$ passive layers are widely used in the construction of Si based electronic devices for the registration of ionising radiation, because of their good isolating properties (Table 2) and high thermoresistivity. Nevertheless, $\mathrm{SiO}_{2}$ is sensitive to radiation damage, represented by the increased generation rate of Frenkel pairs during irradiation $[4,40]$. Isolating properties of the investigated DLC films are comparable to those of $\mathrm{SiO}_{2}$ [41]. However, investigated DLC films are represented by the lower density than $\mathrm{SiO}_{2}$. Due to the fact that a part of detector surface is coated by passive layer, its influence on the X-ray interaction effects in the active volume of the detector was investigated. Modelling results are presented in Table 3. It is evident that there 
Table 2. Properties of coating materials.

\begin{tabular}{lcccc}
\hline Materials & $\begin{array}{c}\text { Elastic modulus, } \\
\text { GPa }\end{array}$ & $\begin{array}{c}\text { Hardness, } \\
\text { GPa }\end{array}$ & $\begin{array}{c}\text { Radiation } \\
\text { damage }\end{array}$ & $\begin{array}{c}\text { Dielectric } \\
\text { constant }\end{array}$ \\
\hline Polyethylene (14\% H, 85\% C & 0.025 & & negligible & $2.35[38]$ \\
Polyethyleneterephthalate (Mylar, 4\% H, 62\% C, 33\% O) & 2.50 & 0.198 & negligible & $3.23[38]$ \\
Rubber (11\% H, 88\% C) & 0.05 & & low & $2.20[38]$ \\
a-C: H (24\% H, 75\% C) & & 15.20 & negligible & 3.77 \\
$\mathrm{SiO}_{x}$-containing DLC (54\% C, 27\% O, 19\% Si) & & 21.00 & negligible & 3.06 \\
$\mathrm{SiO}_{2}$ & 73.0 & 12.35 & medium & 3.89 \\
\hline
\end{tabular}

Table 3. Scatter doses in the active volume of Si detector.

\begin{tabular}{lccc}
\hline Construction & \multicolumn{3}{c}{ Scatter dose, Gy (mA s) } \\
\cline { 2 - 4 } & $25 \mathrm{kVp}$ & $28 \mathrm{kVp}$ & $30 \mathrm{kVp}$ \\
\hline $0.1 \mathrm{~mm} \mathrm{Si}$, uncoated & $1.258 \cdot 10^{-12}$ & $1.236 \cdot 10^{-12}$ & $1.356 \cdot 10^{-12}$ \\
$0.1 \mathrm{~mm} \mathrm{Si}$, coated by $0.001 \mathrm{~mm} \mathrm{SiO}_{2}$ & $1.259 \cdot 10^{-12}$ & $1.239 \cdot 10^{-12}$ & $1.359 \cdot 10^{-12}$ \\
$0.1 \mathrm{~mm} \mathrm{Si}$, coated by $0.001 \mathrm{~mm} \mathrm{a}^{-C}: \mathrm{H}$ & $1.260 \cdot 10^{-12}$ & $1.238 \cdot 10^{-12}$ & $1.361 \cdot 10^{-12}$ \\
$0.1 \mathrm{~mm} \mathrm{Si}$, coated by $0.001 \mathrm{~mm} \mathrm{SiO}_{x}$-containing DLC & $1.260 \cdot 10^{-12}$ & $1.238 \cdot 10^{-12}$ & $1.360 \cdot 10^{-12}$ \\
$0.1 \mathrm{~mm} \mathrm{Si}$, coated by $0.1 \mathrm{~mm} \mathrm{SiO}_{x}$-containing DLC & $1.272 \cdot 10^{-12}$ & $1.288 \cdot 10^{-12}$ & $1.413 \cdot 10^{-12}$ \\
\hline
\end{tabular}

are no differences in the values of the scatter doses in $\mathrm{Si}$ coated by $\mathrm{SiO}_{2}$ layer and $\mathrm{Si}$ coated by DLC layer of the same thickness. Taking into account that the DLC films are less sensitive to radiation damage it is to conclude that DLC films are applicable in the construction of radiation detectors as $\mathrm{SiO}_{2}$ is.

\section{Conclusions}

Monte Carlo modelling of low energy X-ray photon interaction processes in the active volume of $\mathrm{Si}$ detector having different coatings was performed. Results of calculation show increasing tendency of the scatter dose in detector material with the increased density of coating material. However, the gap between the scatter dose in uncoated Si and the dose in Si coated by DLC film, which represents the highest density of the investigated coating materials, was broader for thinner detectors. The scatter dose to total dose ratio was higher in all investigated cases when the thickness of the coating was comparable to the thickness of the active volume, despite of the fact that the scatter dose was lower in the thicker detector.

Photon scattering effects contribute to the decrease of the registered detector signal. Modelling of scattering processes makes it possible to vary coating material, coating thickness, and the geometry of the detector construction and to find the optimal solution for the detec- tor construction corresponding to the enhanced signal to noise ratio.

Modelling results show that extremely thin protective coatings do not influence X-ray interaction processes in detector material, however these coatings have to provide radiation hardness, resistance against chemicals, and suitable mechanical characteristics. DLC films deposited directly onto the active detector surface were found to be promising candidates among all investigated materials. DLC films could be considered as protective coatings when new radiation detectors are under construction. Yet, some problems concerning the adhesive properties of DLC films still exist.

\section{Acknowledgement}

This work was supported by the Lithuanian State Science and Studies Foundation.

\section{References}

[1] J. Van Dam, H. Bosmans, G. Marchal, and A. Wambersie, Characteristics of dosemeter types for skin dose measurements in practice, Radiat. Prot. Dosimetry 117, 185-189 (2006).

[2] M. Hoheisel, Review of medical imaging with emphasis on X-ray detectors, Nucl. Instrum. Methods A 563, 215-224 (2006). 
[3] S.W.S. McKeever, New millennium frontiers of luminescence dosimetry, Radiat. Prot. Dosimetry 100, 2732 (2002).

[4] D.J. Peet and M.D. Pryor, Evaluation of a MOSFET radiation sensor for the measurement of entrance surface dose in diagnostic radiology, The Brit. J. Radiol. 72, 562-568 (1999).

[5] Z. Yin, R.P. Hugtenburg, and A.H. Beddoe, Response corrections for solid state detectors in megavoltage photon dosimetry, Phys. Med. Biol. 49, 3691-3702 (2004).

[6] A.B. Rosenfeld, D. Cutajar, M.L.F. Lerch, G. Takacs, I.M. Cornelius, M. Yudelev, and M. Zaider, Miniature semiconductor detectors for in vivo dosimetry, Radiat. Prot. Dosimetry 120, 48-55 (2006).

[7] A.B. Rosenfeld, A. Wroe, I. Cornelius, and M. Carolan, Verification of Monte Carlo simulations in hadron therapy with non-tissue equivalent detectors, Radiat. Prot. Dosimetry 119, 487-490 (2006).

[8] D. Adlienė and I. Cibulskaite, Evaluation of scattered radiation in mammography examination with $\mathrm{Si}$ detectors, Lithuanian J. Phys. 46, 261-270 (2006).

[9] J.M. Boon, K. Lindfors, K. Cooper, and J.A. Seibert, Scatter/primary in mammography: Comprehensive results, Med. Phys. 27, 2408-2416 (2000).

[10] N. Meric, D. an Bor, and N. Büget, Determination of scatter fractions of some materials by experimental studies and Monte Carlo calculations, Appl. Radiat. Isotopes 51, 161-167 (1999).

[11] M. Bucciolini, F.B. Buonamici, S. Mazzocchi, C.D. Angelis, S. Onori, and G.A. Cirrone, Diamond detector versus silicon diode and ion chamber in photon beams of different energy and field size, Med. Phys. 30, 2149-2154 (2003).

[12] G.A.P. Cirrone, G. Cuttone, L. Raffaele, M.G. Sabini, C. De Angelis, S. Onori, M. Pacilio, M. Bucciolini, M. Bruzzi, and S. Sciortino, Natural and CVD type diamond detectors as dosimeters in hadrontherapy applications, Nucl. Phys. B 125, 179-183 (2003).

[13] S. Tamulevičius, V. Kopustinskas, Š. Meškinis, and L. Augulis, Mechanical properties of ion beam deposited carbon films, Carbon 42, 1085-1088 (2004).

[14] J. Robertson, Diamond-like amorphous carbon, Mater. Sci. Eng. 37, 129-281 (2002).

[15] F. Atchison, T. Brys, M. Daum, P. Fierlinger, A. Foelske, et al., Structual characterization of diamond-like carbon films for ultracold neutron applications, Diamond Rel. Mater. 16, 334-341 (2007).

[16] X.Y. Han, S.J. Zhuo, R.X. Shen, P.L. Wang, G.Y. Tao, and A. Ji, Calculation of the contribution of scattering effects to X-ray fluorescence intensity for coating samples, Spectrochim. Acta, Part B 61, 113-119 (2006).

[17] I. Cibulskaitè and D. Adlienè, Comparison of Monte Carlo simulated scattering processes of low energy photons in radiation detector materials, Nucl. Instrum. Methods A 580, 73-76 (2007).
[18] S.R. Amendolia, M.G. Bisogni, P. Delogu, M.E. Fantacci, M. Novelli, P. Oliva, M. Quattrocchi, V. Rosso, A. Stefanini, and S. Zucca, Experimental study of Compton scattering reduction in digital mammography imaging, IEEE Trans. Nucl. Sci. 49, 2361-2365 (2002).

[19] P. Fajardo, V. Honkimäki, T. Buslaps, and P. Suortti, Experimental validation of multiple scattering calculations with high energy X-ray photons, Nucl. Instrum. Methods B 134, 337-345 (1998).

[20] European Protocol on Dosimetry in Mammography, European Commisson Report EUR 16263EN, ISBN 92-827-7289-6 (European Commission, Luxemburg).

[21] D.R. Dance, C.L. Skinner, K.C. Young, J.R. Beckett, and C.J. Kotre, Additional factors for estimation of mean glandular breast ude using the UK mammography dosimetry protocol, Phys. Med. Biol. 45, 32253240 (2000).

[22] Dosimetric Aspects of Mammography, Report 6 of the Netherlands Commission on Radiation Dosimetry (1993).

[23] K. Cranley, B.J. Gilmore, G.W.A. Fogarty, and I. Desponds, Catalogue of Diagnostic X-ray Spectra and Other Data, Institute of Physics and Engineering in Medicine, Report No 78 (1997).

[24] V. Kopustinskas, ড̌ S. Meškinis, V. Grigaliūnas, S. Tamulevičius, M. Pucèta, G. Niaura, and R. Tomašiūnas, Ion beam synthesis of a-CN $\mathrm{CN}_{x}: \mathrm{H}$ films, Surf. Coat. Technol. 151-152, 180-183 (2002).

[25] J.N. O'Dwyer and J.R. Tickner, Modelling diffractive X-ray scattering using EGS Monte Carlo code, Nucl. Instrum. Methods A 580, 127-129 (2007).

[26] A. Tartari, A. Taibi, A. Bonifazzi, and C. Baraldi, Updating of form factors for coherent scattering of photons in tissues, Phys. Med. Biol. 47, 163-175 (2002).

[27] O. Klein and Y. Nishina, Über die Streuung von Strahlung durch freie Elektronen nach der neuen relativistischen Quantendynamik von Dirac, Z. Phys. 52, 853-864 (1929).

[28] B.K. Chatterjee, L.A. LaJohn, and S.C. Roy, Investigations on Compton scattering: New directions, Radiat. Phys. Chem. 75, 2165-2173 (2006).

[29] R. Ribberfors, Relationship of the relativistic Compton cross section to the momentum distribution of bound electron states, Phys. Rev. B 12, 2067-2074 (1975).

[30] A. Bielajew, Fundamentals of the Monte Carlo Method for Neutral and Charged Particle Transport (The University of Michigan, Ann Arbor, 2001).

[31] I. Kawrakow and D.W.O. Rogers, The EGSnrc Code System: Monte Carlo Simulation of Electron and Photon Transport, Technical Report PIRS-701, 4th printing (National Research Council of Canada, Ottawa, 2003).

[32] D.W.O. Rogers, I. Kawrakow, J.P. Seuntjens, B.R.B. Walters, and E. Mainegra-Hing, NRC User Codes for EGSnrc, Technical Report PIRS-702 RevB (National Research Council of Canada, Ottawa, 2003) (NRC, 2003). 
[33] M. Hoheisel, A. Korn, and J. Giersch, Influence of backscattering on the spatial resolution of semiconductor X-ray detectors, Nucl. Instrum. Methods A 546, 252-257 (2005).

[34] L.M.N. Tavora and W.B. Gilboy, Study of Compton scattering signals in single sided imaging applications using Monte Carlo methods, Nucl. Instrum. Methods B 213, 155-161 (2004).

[35] X.Y. Han, S.J. Zhuo, R.X. Shen, P.L. Wang, G.Y. Tao, and A. Ji, Calculation of the contribution of scattering effects to X-ray fluorescence intensity for coating samples, Spectrochim. Acta, Part B 61, 113-119 (2006).

[36] D. Adlienè, J. Laurikaitienè, and S. Tamulevičius, Modification of amorphous DLC films induced by $\mathrm{MeV}$ photon irradiation, Nucl. Instrum. Methods B 266, 2788-2792 (2008).

[37] D. Adlienè, J. Laurikaitienė, M. Andrulevičius, A. Guobienè, Š. Meškinis, I. Cibulskaitè, and S. Tamulevičius, Mechanical properties of the X-ray ir- radiated DLC films containing $\mathrm{SiO}_{x}$ as a constructive element for radiation detectors, Nucl. Instrum. Methods A 591, 188-191 (2008).

[38] Relative Dielectric Constant $\varepsilon_{r}$ (dk Value) of Liquids and Solid Materials (Endress and Hauser Messtechnik, Germany, 2000).

[39] Š. Meškinis, V. Kopustinskas, K. Šlapikas, S. Tamulevičius, A. Guobienè, R. Gudaitis, and V. Grigaliūnas, Ion beam synthesis of the diamond like carbon films for nanoimprint lithography applications, Thin Solid Films 515, 636-639 (2006).

[40] M. Petasecca, F. Moscatelli, D. Passeri, G.U. Pignatel, and C. Scarpello, Numerical simulation of radiation damage effects in $p$-type silicon detectors, Nucl. Instrum. Methods A 563, 192-195 (2006).

[41] Y. Qi, Z.G. Xiao, and T.D. Mantei, Comparison of silicon dioxide layers grown from three polymethylsiloxane precursors in high density oxygen plasma, J. Vac. Sci. Technol. A 21, 1064-1068 (2003).

\title{
MAŽOS ENERGIJOS RENTGENO SPINDULIUOTĖS SKLAIDOS MODELIAVIMAS DETEKTORIUOSE SU APSAUGINĖMIS DANGOMIS
}

\author{
I. Cibulskaitè, D. Adlienè, J. Laurikaitienė
}

Kauno technologijos universitetas, Kaunas, Lietuva

\begin{abstract}
Santrauka
Pristatomi mažų energijų Rentgeno fotonų sąveikos su Si detektoriumi Monte Karlo modeliavimo rezultatai, leidžiantys įvertinti įvairių detektoriaus apsauginių dangų įtaką dozėms, registruojamoms detektoriuje. Tyrimui pasirinktos detektoriu konstrukcijos su apsauginemis polimerinio tipo anglies bei deimanto tipo anglies dangomis. Šiems detektoriams apskaičiuotos pilnoji bei sklaidos dozès, pagal kurias vertinta apsauginès dangos elementinès sudè-
\end{abstract}

ties bei storio itaka Rentgeno fotonų sklaidai Si detektoriuje. Aptariamas detektorių su apsaugine danga vertinimas pagal mažiausios išsklaidytų fotonų frakcijos, lyginant su pilnaja sugertaja doze, kriterijų. Parodyta, kad dèl išskirtinių mechaninių savybių, atsparumo cheminiam poveikiui bei radiaciniams pažeidimams deimanto tipo anglies dangos, tiesiogiai nusodintos ant detektoriaus paviršiaus, yra perspektyvios konstruojant fotonų detektorius. 